Bangladesh Journal of Anatomy July 2013, Vol. 11, No. 2 pp. 71-76

\title{
Comparison of the Stature and Lower Limb Segment Lengths between Santhals and Banglalees of Pirganj, Rangpur
}

\author{
Sultan Ahmed ${ }^{1}$, Afruza Bulbul Akhter ${ }^{2}$, Selina Anwar ${ }^{3}$, Anjum Ara Begum ${ }^{4}$, \\ Khalilur Rahman ${ }^{5}$, Narayan Chandra Saha ${ }^{6}$
}

\begin{abstract}
Context: The relationship between height and long bone differs according to race, age, sex and size of the body. Anthropometric studies of bones convey information regarding race, sex, age and stature of a person. This information is of immense interest to the anatomist in the academic field as well as medico legal work. Climates, heredity, nutritional status of population are reported to have an effect on stature and length of long bones.
\end{abstract}

The study was aimed at to the anthropometric measurement of stature and length of different segments of lower limb of adult Santhal males of Pirganj upazilla, Rangpur to find out any racial characteristics of their own and compared with Bangalee adult males of the same area to find out any racial variations between these two groups of populations.

Materials and Methods: Stature is the standing height of a person. The study was done on 60 adult male Santhals and 120 adult male Bangalees. Measurements stature and different lower limb segment length (upper leg segment length, lower leg segment length, leg segment length) was done.

Results :It was seen from the result of the present study that though height and upper leg segment length was higher in Bangalees than the Santhals, the lower leg segment length and leg segment length was significantly higher in the Bangalee males than the Santhals.

Conclusion: The present study shows that the lower leg segment length and leg segment length was significantly higher in the Bangalee males than Santhals due to nutritional deficiency.

Key words : Santhals, Bangalees, upper leg segment, lower leg segment

\section{Introduction}

All human beings occupying this globe belong to the same species i.e. Homo sapiens, meaning intelligent human. But no two individuals are exactly alike in all their measurable traits. These traits tend to undergo change in varying degrees from birth to death, in health and disease. Since skeletal development is influenced by a number of factors

1. Associate Professor, Department of Anatomy, Rangpur Medical College

2. Professor, Department of Anatomy, Rangpur Community Medical College

3. Professor, Department of Anatomy, Rangpur Medical College

4. Professor, Department of Anatomy, Prime Medical College

5. Associate Professor, Department of Anatomy, Rangpur Medical College

6. Assistant Professor, Department of Anatomy, Rangpur Medical College

Correspondence: Dr. Sultan Ahmed producing differences in skeletal proportions between different geographical areas, it is desirable to have some means of giving quantitative expression to variations which such traits exhibit. Anthropometry constitutes that means, as it is the technique of expressing quantitatively the form of the human body ${ }^{1}$

Several studies elsewhere have investigated the anthropometric characteristics and nutritional status of adults of different ethnic groups.2,3,4,5,6,7 Information is scarce on the anthropometric and nutritional status of various tribal population of Bangladesh. Santhals are one of the largest tribal community in Bangladesh. They live in greater district of Rangpur, Dinajpur and Rajshahi. Total population of Santhals in Bangladesh is about 2, 
26,000 and in Chatra union of Pirganj Upazilla their total number is about $8000^{8}$

The stature prediction occupies relatively a central position in the anthropological research. The changes of relationship between bone length and body stature have been reported. It is generally recognized that the stature varies not only with the limb segment lengths but is also influenced by factors such as body width, bone thickness, and muscularity ${ }^{9}$.

\section{Materials and Methods}

The study was done on 60 adult male Santhals and 120 adult male Bangalees.

The lower limb segment lengths are sum total of upper leg segment length, lower leg segment length and foot height.

Stature (height) of the person was measured from vertex to the sole of the foot with a stadiometer or height scale to the nearest $0.1 \mathrm{~cm}$.

All the measurements were done on the right lower limb according to Sukhgill ${ }^{11}$

The measurement of upper leg segment length was done with the subject sat straight on the chair with the right knee bent at 90angle. A measuring tape was placed at the middle of inguinal crease and extended along the midline of the upper leg segment to the line just proximal to the patella.

Measurement of lower leg segment length was done with the subject in sitting position with the legs positioned vertically downwards and the soles resting on the floor. Then measurement was from the proximal medial condyle of the tibia to the sole of the foot along the medial aspect of the leg, with a measuring tape.

Measurement of leg segment length was done with the subject in sitting position, the legs positioned vertically downwards and the soles resting on the floor. It was measured from the proximal medial condyle of the tibia to the most prominent point of medial malleolus of the tibia.

\section{Results}

Stature (height):

Table 1 shows that the mean stature of the Bangalees was $162.9 \pm 5.3 \mathrm{~cm}$ and that of Santhals subjects was $161.9 \pm 5.6 \mathrm{~cm}$, but the mean difference was not statistically significant $(p>0.05)$. Data shows that the Bangalees subjects were little bit higher than the Santhals. In figure 1, bar diagram shows that the highest proportions of subjects (40\%) were distributed between 161 and $165 \mathrm{~cm}$ for both Bangalees and Santhals for stature. The second highest frequencies of subjects were distributed between 156 and $160 \mathrm{~cm}$. The proportion was $27.5 \%$ and $23.33 \%$ in Bangalees and Santhals respectively.

\section{Upper leg segment length:}

Table 1 shows though the upper leg segment was little bit higher among the Bangalees $(41.0 \pm 2.3 \mathrm{~cm})$ than the Santhals $(40.8 \pm 2.2 \mathrm{~cm})$, but the difference was not statistically significant ( $p>0.05)$. In figure 2 , bar diagram shows that the highest proportions of subjects for upper leg segment length were distributed between 37.51 and $40.50 \mathrm{~cm}$ and between 40.51 and $43.50 \mathrm{~cm}$. The proportions were $41.67 \%$ for Bangalees in both ranges but the Santhals were $40 \%$ and $38 \%$ respectively at these ranges.

Lower leg segment length:

Table 1 revealed that the mean length of lower leg segment was higher among the Bangalees subjects $(45.7 \pm 1.9 \mathrm{~cm})$ than the Santhals $(45.0 \pm 2.1 \mathrm{~cm})$ and the mean difference was statistically significant $(P<0.05)$. In figure 3 , bar diagram shows that for lower leg segment length, the highest proportions of Bangalees subjects (35\%) were distributed between 45.49 and $46.97 \mathrm{~cm}$ followed by $25.83 \%$ between the ranges of 44 and $45.48 \mathrm{~cm}$. But the proportion of Santhals was more in the later range (33.33\%) than the former range (16.67\%). Again the proportions of Bangalees were more towards the highest length $(22.5 \%)$ than the Santhals (18.33\%)

Leg segment length:

Table 1 show that the mean leg segment length of the Bangalees was $38.6 \pm 2.1 \mathrm{~cm}$ ranging from 34 
to $48 \mathrm{~cm}$ whereas the mean leg segment length of the Santhals subjects was $37.9 \pm 1.7 \mathrm{~cm}$ ranging from 34 to $43 \mathrm{~cm}$. The mean difference was statistically significant $(p<0.05)$ indicating the mean length was higher among the Bangalees than the Santhals. In figure 4 bar diagram shows that the highest proportion of subjects for leg segment length were distributed between 36.51 and $38.50 \mathrm{~cm}$. The proportions were $47.5 \%$ for Bangalees and $53.33 \%$ for Santhals. The second highest proportions of subjects were distributed between 38.51 and 39.50 $\mathrm{cm}$. The proportions were equal $(25 \%)$ both in Bangalees and Santhals. Again the proportions of Bangalees were high towards the highest leg segment length (which may cause the significantly higher length of leg segment in Bangalees).

Table-I

Distribution of the subjects by stature and lower limb measurements.

\begin{tabular}{|c|c|c|c|c|}
\hline \multirow[t]{2}{*}{ Variables (cm) } & \multicolumn{2}{|c|}{ Subjects } & \multirow{2}{*}{$\begin{array}{c}\text { Total } \\
(\mathrm{n}=180)\end{array}$} & \multirow[t]{2}{*}{ p value } \\
\hline & $\begin{array}{c}\text { Bangalees } \\
(n=120)\end{array}$ & $\begin{array}{l}\text { Santhals } \\
(n=60)\end{array}$ & & \\
\hline Stature & $162.3 \pm 5.3$ & $161.9 \pm 5.6$ & $162.2 \pm 5.4$ & 0.667 \\
\hline (cm) & $145.0-174.0$ & 151.0-178.0 & $145.0-178.0$ & \\
\hline Upper leg & $41.0 \pm 2.3$ & $40.8 \pm 2.2$ & $40.9 \pm 2.2$ & 0.577 \\
\hline segment length & $(34.5-49.0)$ & $(37.0-46.0)$ & $(34.5-49.0)$ & \\
\hline Lower leg & $45.7 \pm 1.9$ & $45.0 \pm 2.1$ & $45.4 \pm 2.0$ & 0.031 \\
\hline segment length & $(41.6-51.0)$ & $(41.0-51.0)$ & $(41.0-51.0)$ & \\
\hline Leg segment & $38.6 \pm 2.1$ & $37.9 \pm 1.7$ & $38.4 \pm 2.0$ & 0.025 \\
\hline length & $(34.0-38.0)$ & $(34.0-43.0)$ & $34.0-48.0$ & \\
\hline
\end{tabular}

$\mathrm{p}$ value reached from unpaired $\mathrm{t}$ test

Results are shown as ranges and meanSDs.

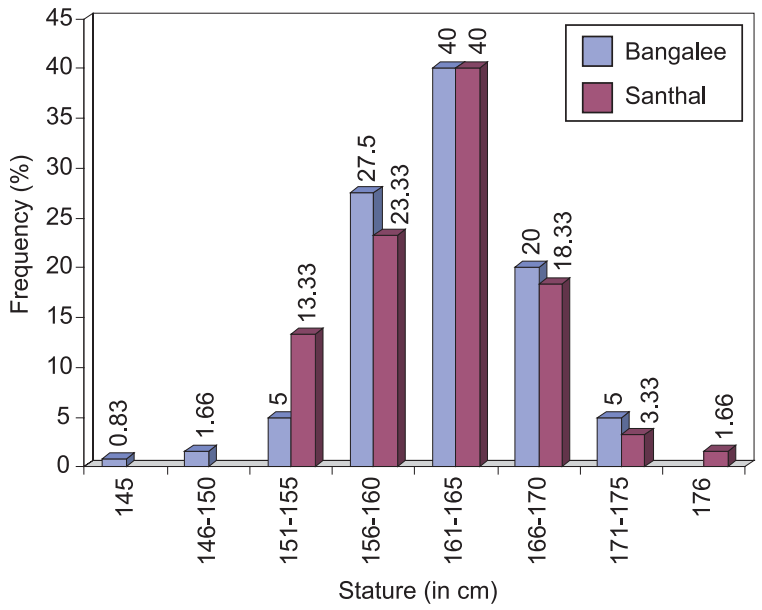

Fig.-1: Bar diagram showing the distribution of stature in Bangalees and Santhals.

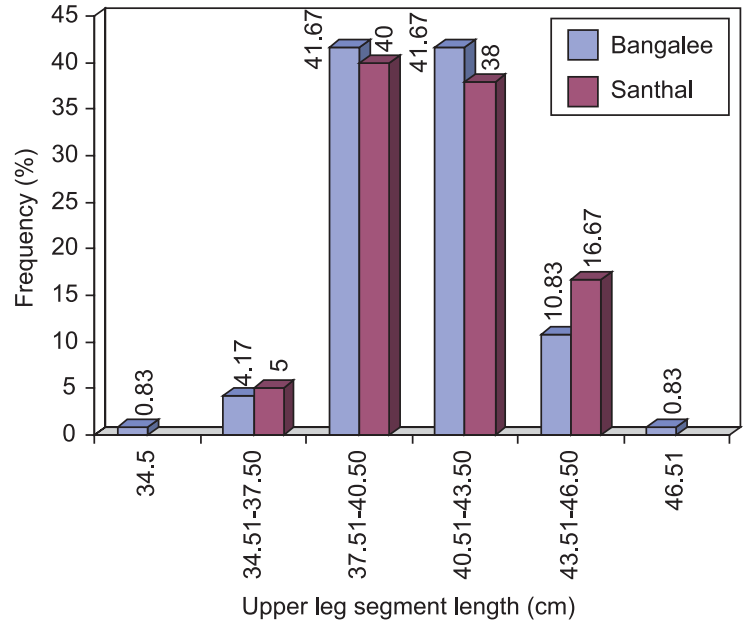

Fig.-2: Bar diagram showing the distribution of upper leg segment length in Bangalees and Santhals. 


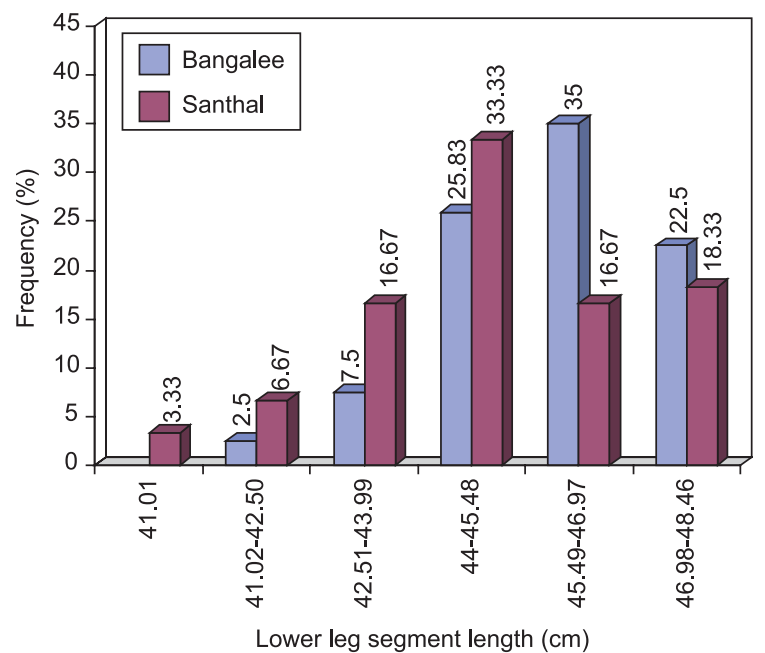

Fig.-3: Bar diagram showing the distribution of lower leg segment length in Bangalees and Santhals.

\section{Discussion}

The community who has been living in any country earlier than any other community is called "aborigines". "Aborigine or indigenous" means from the beginning. The first living society of Bangladesh is the "Bangalees". So, in this sense reasonably the real aborigine of Bangladesh is the Balgalees ${ }^{12}$. More than 20 anthropological communities are crowded in different parts of Bangladesh; they are migrated into this area from south from the sixteenth to the nineteenth centuries. Now a day, they become part of this country getting mixed with its root. They are described as the tribes of Bangladesh, one of them are Santhals. In Bangladesh, they live in greater district of Rangpur, Dinajpur and Rajshahi.

Santhals are dark complexioned, flat nosed, thick lipped, with curly hairs and of medium height. For these reasons, they are classified as pre-Dravidian, as this class of people once came from Australia to the sub-continent. According to the theories of modern anthropology some experts are of the view that the Santhals are proto Austroloids as they are migrated from Australia

Gosh and Malik stated that Santhals are shortstatured but they have long legs and long arms with broad shoulders.

The difference in the body size and shape is common phenomenon in human populations. But

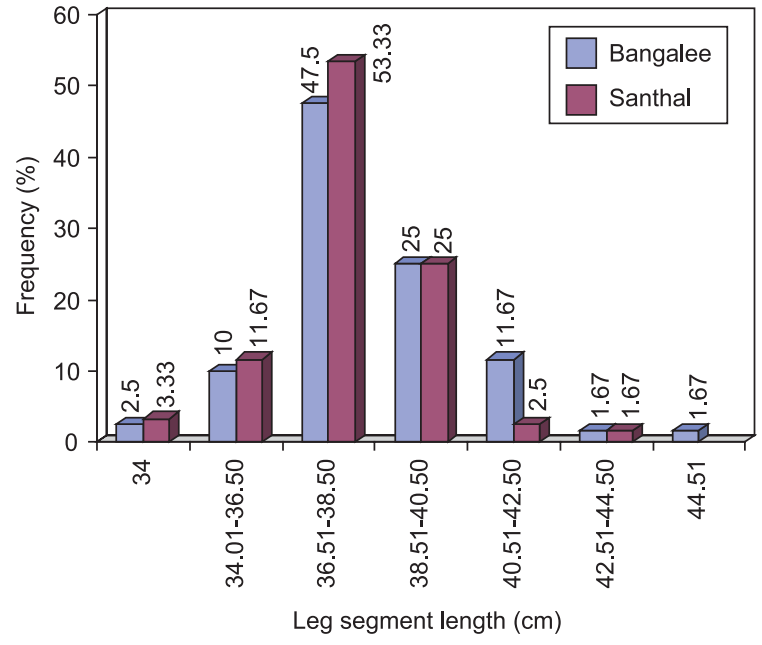

Fig.-4: Bar diagram showing the distribution of leg segment length in Bangalees and Santhals.

in areas where survival is based on physical labor, each member of those areas has to perform laborious work irrespective of race. Studying inter population variations in different morphological characteristics such as stature and length of the different lower limb segment lengths have long been an interest of Anthropologists. Inter populational morphological variations are influenced by macro and micro environmental factors like socioeconomic condition, nutritional status, climatic condition, physical setting of the habitat and level of physical work. As a consequence, human populations possess characteristics that stamp them as residents of particular areas of the world.

The development of human skeletal system is influenced by a numbers of factors producing differences in skeletal proportions among the different geographical areas. Physical measurements are used in children to see the nutritional status and congenital anomalies.

The relationship between height and long bone differs according to race, age, sex and size of the body. Climates, heredity, nutritional status of population are reported to have an effect on stature and length of long bones. Therefore an appropriate evaluation of individual variability in height should include some measurements that reflect the sum 
of these factors. The relationship between height and long bone differs according to race, age, sex and size of the body. Climates, heredity, nutritional status of population are reported to have an effect on stature and length of long bones. Therefore an appropriate evaluation of individual variability in height should include some measurements that reflect the sum of these factors.

Santhals in Chatra union of Pirganj Upazilla are babtized into Christian. They are poor and belong to low socioeconomic class. The primary occupation of Santhals in the Chatra Union is agriculture, though food gathering and haunting are their important subsidiary economic pursuits. In term of nutritional intake, they take their meal together twice in a day. In the morning the take breakfast which consists of cold rice, prepared with the evening meal of previous day and is kept for the morning. The meal consistent of only boil rice with little amount of local vegetables. They seldom intake protein and fat containing diet. Santhals in Pirganj also take Jungle potatoes, goose, jungle snakes and mircat (one kind of wild animal). Personal hygiene and health status are satisfactory among Santhals.

The Bangalee population of this study was from a poor socioeconomic group to maintain similarities with the Santhals. Though no significant difference in stature was found between the Santhals $(161.9 \pm 5.6 \mathrm{~cm})$ and Bangalees $(162.3 \pm 5.4 \mathrm{~cm})$, the mean height was more in Bangalee group.

Ghosh and Malik worked on 400 adult male Santhals in the Bankura district of West Bengal and found their mean stature was $159.84 \pm .32 \mathrm{~cm}$ which was less than the present study.

The present study shows that the Santhal males are taller than that of the Santhals of India.

Again, in the present study there was no statistically significant difference found between Banglalees and Santhals in the mean length of individual upper and lower leg segment $(p>0.05)$ though the mean upper and lower leg segment length was high in Bangalees than the Santhals.

But in present study the mean length of leg segment (the sum total of the lower leg segment length and foot height) was significantly higher in among the
Bangalees than the Santhals $(p<0.05)$. According to the present study the total length of the lower limb was about $78 \mathrm{~cm}$ which is much less than total length of the lower limb $(91.7 \pm .3 \mathrm{~cm})$ found by Ghosh and Malik 4

According to Ghosh and Malik Santhals are shortstatured. Almost all Santhals of West Bengal have long legs and long arms with broad shoulders. Such a kind of physique allows greater heat dissipation and lesser heat gain; as a consequence, it is advantageous for population living in hot and humid climatic conditions, such as that of Santhals of Bakura. Allen's rule cited by Gosh and Malik stated that within a polytypic worm blooded species there is an increase in the relative size of the protruding organs such as extremities, ears and appendages with the increase in temperature of its habitat. Hence long upper and lower extremities of Santhals help them to adapt and survive efficiently in the hot climatic conditions of their surrounding. Besides, they are underweight in general. Succinctly, the Santhals of west Bengal is a population with efficient adaptive mechanism. But according to the present study the Santhals have significantly shorter lower limbs than the Bangalees. The shorter lower limbs may result in the lower value in stature in the Santhals in the present study. Again Ghosh and Malik did not compare the Santhals of Bankura of the non-tribal peoples living in that region.

\section{References}

1. Krishan K. Anthropometry in Forensic Medicine and Forensic Science-'Forensic Anthropometry'. The Internet Journal of Forensic Science 2007; 2(1): 95-97.

2. Bhasin MK and Jain S. Age changes in somatotype, Biology of tribal groups of Rajasthan, India 2007.

3. Ghosh S and Malik SL. Sex differences in body size and shape among Santhals of West Bengal, India 2007.

4. Banik SD. Nutritional status in adult men from the Oraon tribe in Ranchi district of Jharkhand, India 2008. 
5. Bisai S and Bose K. Body mass index and chronic energy deficiency among adult tribal populations of West Bengal, India 2008.

6. Ghosh S and Malik SL. Auditing gender equality among Santhals, Bankura district, West Bengal, India. 2009. http:// www.isical.ac.in/ wemp/Papers/ PaperSudiptaGhosh.doc.

7. Kaur M. Age changes in somatotype components of rural and urban Panjabi Brahmin Females, India 2009.

8. Joshua Project: A ministry of the U.S. Center for World Mission Direct URL to this page: http://www.joshuaproject.net/countries. php?rog3=BG
9. Carter JEL and Heath BH. SomatotypingDevelopment and Applications. Cambridge: Cambridge University Press 1990.

10. Akhtar P. An anthropometric study of lower limb segment lengths measurements and their relationships with the stature. Dhaka, Bangladesh 2006.

11. Junk S, Lee S, Boo j, Park J. Classification of foot types for designing footwear of the Korean elderly. $5^{\text {th }}$ Symposium. On footwear biomechanics, Zurich, Switzerland 2001. 48-49.

12. Sagor KA. History of Adibashi of Bangladesh. 2nd ed. Dhaka: Patraput 2008. 115-126. 